\title{
A socially inclusive teaching strategy for fourth grade English (second) language learners in a South African school
}

\begin{tabular}{|c|c|}
\hline \multicolumn{2}{|c|}{$\begin{array}{l}\text { Authors: } \\
\text { Mots'elisi L. Malebese }{ }^{1} \text { (D) } \\
\text { Moeketsi F. Tlali' } \\
\text { Sechaba Mahlomaholo }\end{array}$} \\
\hline \multicolumn{2}{|c|}{$\begin{array}{l}\text { Affiliations: } \\
{ }^{1} \text { Community-Based } \\
\text { Educational Research } \\
\text { (COMBER), North-West } \\
\text { University, Potchefstroom, } \\
\text { South Africa }\end{array}$} \\
\hline \multicolumn{2}{|c|}{$\begin{array}{l}{ }^{2} \text { School of Mathematics, } \\
\text { Natural Sciences and } \\
\text { Technology Education, } \\
\text { University of the Free State, } \\
\text { Bloemfontein, South Africa }\end{array}$} \\
\hline \multicolumn{2}{|c|}{$\begin{array}{l}{ }^{3} \text { Teaching and Learning, } \\
\text { University of Zululand, } \\
\text { Richards Bay, South Africa }\end{array}$} \\
\hline \multicolumn{2}{|c|}{$\begin{array}{l}\text { Corresponding author: } \\
\text { Mots'elisi Malebese, } \\
\text { motsilisimalebese@yahoo.com }\end{array}$} \\
\hline \multicolumn{2}{|c|}{$\begin{array}{l}\text { Dates: } \\
\text { Received: } 28 \text { Oct. } 2016 \\
\text { Accepted: } 01 \text { Sept. } 2018 \\
\text { Published: } 25 \text { Apr. } 2019\end{array}$} \\
\hline \multicolumn{2}{|c|}{$\begin{array}{l}\text { How to cite this article: } \\
\text { Malebese, M.L., Tlali, M.F. \& } \\
\text { Mahlomaholo S., 2019, } \\
\text { 'A socially inclusive teaching } \\
\text { strategy for fourth grade } \\
\text { English (second) language } \\
\text { learners in a South African } \\
\text { school', South African Journal } \\
\text { of Childhood Education 9(1), } \\
\text { a503. https://doi.org/ } \\
\text { 10.4102/sajce.V9i1.503 }\end{array}$} \\
\hline \multicolumn{2}{|c|}{$\begin{array}{l}\text { Copyright: } \\
\text { (C) 2019. The Authors. } \\
\text { Licensee: AOSIS. This work is } \\
\text { licensed under the Creative } \\
\text { Commons Attribution } \\
\text { License. }\end{array}$} \\
\hline \multirow{2}{*}{ 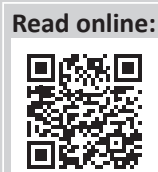 } & \\
\hline & $\begin{array}{l}\text { Scan this QR } \\
\text { code with your } \\
\text { smart phone or } \\
\text { mobile device } \\
\text { to read online. }\end{array}$ \\
\hline
\end{tabular}

Background: Learners from predominantly less priviledged South African schools encounter English as a language of teaching and learning for the first time in Grade 4. The transition from the use of home language to second language, namely English first additional language, is complexly related to the learners' inability to read text meaningfully. This complexity is traceable to the reading materials, actual teaching practices and learners' cultural underpinnings. Learners' inability to read text meaningfully impacts negatively their academic performance in general.

Aim: This article demonstrates how a socially inclusive teaching strategy is used to enhance the teaching of reading in a second additional language to Grade 4 learners.

Setting: A one-teacher public school situated on a remote private property with bad access roads. Learners from neighbouring farms walked long distances to school. The teacher's administrative work and workshops often clashed with teaching and learning that received very limited support.

Methods: The principles of the free attitude interview technique and critical discourse analysis were used to generate and analyse the data. Socially inclusive teaching strategy that is participatory action research-oriented and underpinned by critical emancipatory research principles guided the study.

Results: The use of socially inclusive teaching strategy helped improve reading of English text significantly.

Conclusion: Socially inclusive teaching strategy can help improve learning and teaching support materials, teacher support and learning.

Keywords: socially inclusive teaching strategy; critical emancipatory paradigm; English First Additional Language; critical discourse analysis; public farm school.

\section{Introduction}

Global research proved that transitioning from a home language to a second additional language impacts learning adversely. According to the literature, this is exacerbated when learners are not adequately prepared in their respective home languages (Madiba 2013:4; UNESCO 2012:2; Wetere 2009:3). In the context of South Africa (SA), the second language is known as English First Additional Language (EFAL) and it is also one of the languages of teaching and learning (LoTL). This means that learners from the transitioning grade - Grade 4 - are taught subjects such as mathematics, natural science and life orientation in English. Learners in rural public farm schools, similar to their urban counterparts, are taught in English and are expected to learn to read using similar books. This aspect is worsened by the fact that the learners from rural public schools (as is the case in this study) are expected to read books that predominantly depict urban content and context. Learners with rural backgrounds find no tangible value in books with urban content and are therefore reluctant to engage in reading.

The studies regarding learners' literacy competency indicate that Grade 4 learners, especially in rural settings and learning using the SA curriculum, are unable to read text meaningfully (Department of Basic Education [DBE] 2011:45, 2014:8; Ofulue 2011:12; UNESCO 2012:2; Wetere 2009:3). The problems they encounter include synthesising information, making informed decisions and communicating effectively (Alberta Education 2010:1; DBE 2011:45; Taylor 2016:11). The inability to hear and differentiate between different sounds means learners are unable to pronounce words correctly, and they lack the ability to express themselves logically and fluently. In short, 
learners in Grade 4 are unable to adapt fully to EFAL (DBE 2009:40, 2011:7, 2014:20; Kirby, Griffiths \& Smith 2014:108; Scharer 2012:2). This has a ripple effect on their performance in other subjects, which may be attested to the relatively high failure rates. As such, the majority of learners are progressed to the next grades as a result of age or number of years in a grade instead of actual competences in the respective subjects (Bruwer, Hartell \& Steyn 2014; Weybright et al. 2017).

The learners' perceived inability to adapt fully to EFAL may well mean that they are not adequately prepared in their home language. During the investigation, the authors found that the teachers play a significant role in these situations, which deserved deeper scrutiny. The study was conducted at a primary public farm school with an enrolment of 36 learners in grades 1-6. Only one teacher has to teach all the learners; thus, she has to apply multigrade teaching strategies to teach subjects such as home language (Sesotho), second language, namely EFAL, numeracy and mathematics, life orientation and natural science. Six of these learners were in Grade 4, which was the focus of this study. Two of these Grade 4 learners did not meet the minimum progression requirements in Grade 3. They were progressed to Grade 4 in accordance with the policy requirement that learners may not repeat a grade more than twice (Corcoran 2010). Four out of 11 learners in Grade 5 were progressed to Grade 5 because of the above-mentioned policy instead of their actual performance and competence. What may have worsened the learning process is that EFAL classes were missed because of the teachers' other administrative and training engagements. These reduced the teaching and learning time and affected it adversely.

In addition, the teacher may have applied her teaching strategies in a manner that rendered them ineffective and may not have provided much assistance when teaching EFAL reading. As a result, the study also accommodated four Grade 5 learners; thus, the research sample consisted of 10 learners. Several strategies used in an attempt to respond to the challenges related to teaching of reading seem to have been ineffective because the learners' reading problems persisted. The majority of these strategies encouraged rote learning, regarded the teacher as the only knowledgeable source and were teacher-centred teaching (Vygotsky 1978:1). The context painted above suggested the need for a unique way of responding to these challenges. As a result, the authors considered using social inclusive teaching strategies (SITS) to enhance the teaching of EFAL in the Grade 4 class under research. The research question was the following: 'how can SITS be used to enhance the teaching of reading EFAL to Grade 4 learners at a public farm school?' The question addressed the need to respond to learners' inability to read text meaningfully and fluently, and to address their difficulty in writing or expressing themselves logically in EFAL.

\section{Socially inclusive teaching strategy}

Social inclusive teaching strategies are based on the principles of critical emancipatory research (Mahlomaholo 2013:2), which evolved from critical theory within the transformative paradigm (Mertens \& Yamashita 2010:48). Thus, SITS stem from and are informed by the ontological and epistemological stances of the transformative paradigm. SITS contend that reality is contextual and knowledge is socially created (Mertens \& Yamashita 2010:48).

In this case, reality refers to the contextual challenges experienced by Grade 4 EFAL teachers in rural settings (a school situated in rural area). These challenges may not be generalised to all contexts. Epistemologically, SITS posit that residents in the affected rural area have a wealth of knowledge originating from their culture, which they can contribute to enhance the teaching of EFAL to Grade 4 learners. Thus, SITS are amenable to the application of various teaching approaches relating to the diverse backgrounds of the stakeholders involved. SITS consider the learning needs of learners from different backgrounds, as well as their learning styles and capabilities (Armstrong 2011:52). Furthermore, SITS are sensitive to the prevalence and abuse of power. By adopting the values of mutual respect and care (Malebese 2016:82), they insistently work to level differential ideological and power realities and accommodate diversity.

In this way, SITS have the potential to facilitate the creation of sustainable learning environments in which learners feel equally valued and in which their reading and writing skills are improved. In this way they are given hope that they could access quality education as envisioned by policy and public mandates (Devereaux 2013:1). Thus, SITS promote social cohesion (Department of Education 2005:98; Faulker 2011:19). They encourage learners and teachers to talk to one another about real-life situations, and position language to serve the purpose of communicating real ideas and solutions to real-life problems (Mahlomaholo 2013:2). In this sense, the aim of SITS is to create a classroom environment that can include all learners, and allow them to voice their views freely (Shepherd 2012:1; Woolfolk 2007:47). Shepherd (2012:1) maintains that knowledge is conveyed and accomplished through collaborative work. Therefore, providing access to resources and services will provide additional support to school staff, learners and learners' families, and will contribute to the development and implementation of healthy school initiatives (Das \& Kattumuri 2011:4; Desforges \& Abouchaar 2003:78; Eggen \& Kauchak 2008:331; Pedretti \& Nazir 2011:4).

Social inclusive teaching strategies help us to pursue our indepth understanding of the actual teaching practices of EFAL in the context of the learners' experiences and backgrounds. They also assist in interrogating EFAL reading material with a view to integrate the community's wealth of cultural participants (Yosso 2005). These issues influenced the design significantly.

\section{Design}

This article relates to a need for an in-depth understanding of the teaching of reading in the second language, namely EFAL, of learners who encounter second language for the 
first time (Grade 4) as LoTL. The uniqueness of this case lies inter alia in the following: a one teacher school, situated on a privately owned property (farm) where community members have little or no role to play in support of the teaching of reading in particular. This case was complex and thus warranted the involvement of other stakeholders and community members for comprehension. It (case) needed to be deconstructed in order to reconstruct alternative views and understanding relating to the teaching of reading in EFAL (Thomson, Hall \& Jones 2013).

Thus, the authors worked as a team, comprising four members, in order to share the load while learning from experiences to enhance the teaching of reading in EFAL. The authors participated in the study because they felt obliged to find ways to improve the teaching of reading in EFAL in Grade 4 (Kemmis \& McTaggart 2007). This was done without disturbing or causing conflict with the study's basic interests and commitments. Participation in the study and the team was open to other participants depending on their interests and the contribution they could make (Burnes \& Cooke 2013:411). The efforts and activities were coordinated by the study coordinator (the first author hereto). The other two members were unemployed youth who served as teacher's aides. They had both passed Grade 12 the year before this study was undertaken. The key role of the teacher's aides was to help the teacher with teaching learners to read in EFAL, in line with the aim of this study. The EFAL teacher was the fourth member and was responsible for all the classroom activities.

Ethical considerations were central to the establishment of the team (Henning, Van Rensburg \& Smith., 2004). The participants were informed about permission sought from and given by the university and the school. The participants' consent and learners' assent were also requested. Prospective participants' rights to confidentiality and withdrawal from the project were also explained so that participants could make informed decisions.

\section{Data generation}

The authors used the principles of free attitude interview (FAI) as the technique to generate data (Meulenberg-Buskens 1996). This technique enabled them to interview the two main sources of data pertaining to the main question. The two data sets were the depth of Grade 4 reading material that engendered reading in EFAL as well as the teachers' related teaching practices and strategies for teaching reading in EFAL. The interviews entailed robust engagement through questioning, clarity seeking and follow-up questions that culminated in summaries of information pertaining to the data set under consideration. The summarised versions of these specific issues served as data, because they essentially represented team members' consensus. The person who summarised each aspect would, for instance, solicit confirmation of statements from others by asking, 'do we agree that ...' or 'so, what are we saying? ... are we saying that ...' Where necessary, further confirmation was derived during the iterative and inter-subjective reflection sessions.
The transcripts of the voice-recorded engagements further eased ratification of the data.

The initial questions and/or thought-provoking statements were based on the following:

- The (contextual) specific realities/issues relating to learners' EFAL readers (reading material). A question that was asked is: 'in what ways do learners' EFAL readers ease and promote the teaching of reading in EFAL?' The team first ensured that everyone understood the question and/or the statement well before providing responses. This was achieved by giving examples, alternative statements and/or rephrasing questions.

- Actual teaching of reading in EFAL experiences and practices. In the same way as with the first source of data, data were generated through robust questioning of the actual teaching. The team sought to establish the extent to which the usual teaching of reading in EFAL contributed towards learners' difficulties of reading in EFAL. To this extent, the following question was asked: 'how does the "usual" teaching of EFAL contribute to the learners' reading difficulties?'

Van Dijk's critical discourse analysis was used to analyse the data in order to make sense of the discourses (Van Dijk 2009:256). The discourses were traced from textual, through cognitive, to social structural levels (Van Dijk 2003:256). These levels of analysis are consistent with the analytical, interpretive and educative stages of critical emancipatory research that helped conceptualise SITS (Chomsky \& Foucault 2006:17; Kincheloe \& Steinberg 1998; Mahlomaholo 2013). By applying critical discourse analysis, the constructs and priorities pertaining to each of the two sources of data (data sets) were unearthed.

\section{Analysis and discussion of findings}

The data analysed below were generated during the iterative, reflective and participatory action researchoriented engagements.

\section{Reading workbooks}

Stories in the Grade 4 EFAL readers that promote the enhancement of teaching reading in EFAL consider that Grade 4 learners encounter EFAL as a subject and LoTL for the first time (Ehri 2005; Feiman-Nemser 2001; Gentry 2010; Nel \& Müller 2010). This means that their immediate background and socio-cultural experiences dominate their knowledge base more than the remote and foreign environments. Thus, the organisation, content and its sequencing in the story are consistent with this principle. Stories are organised and content sequenced progressively 'from the known to the unknown' and from 'the concrete to the complex' (Christie, Enz \& Vukelich 2011; Jarman et al. 2012). The identification of letters and sounds in isolation and in words, the ability to spell and pronounce words correctly and fluently, as well as the understanding of the meaning[s] of words are basic to teaching reading. 
Stories that encourage the teaching of reading provide brief and clear headings that guide the readers' anticipation of the text. Following the heading is the pictorial depiction of the story to cater for visual learners' learning style and to provide detailed information about the story. Another aspect of these kinds of stories is the identification of important words that appear in the story. These words serve to build and enrich learners' vocabulary. They motivate learning how to spell words correctly and pronounce them fluently. In addition to fully understand the meaning of words, one has to associate and integrate them with, and in, one's prior knowledge and experiences of similar meanings from one's background and home language. In so doing, the relevance and meaningfulness of the words are realised.

The authors traced the progression discussed immediately above from the stories in the Grade 4 learners' readers. They focussed on the three learners' readers (reading materials) that were available at the school at the time of this study. The stories in the learners' readers appeared to be limited with regard to progressive organisation of content and sequencing as shown in Figures 1 and 2.

The story in Figure 1 was from a reader that is not prescribed for Grade 4. It was mainly used by the teacher's aides during afternoon classes to help learners who were found to be slow in reading. The prescribed readers were only used during normal school hours and learners were not allowed to take them home.

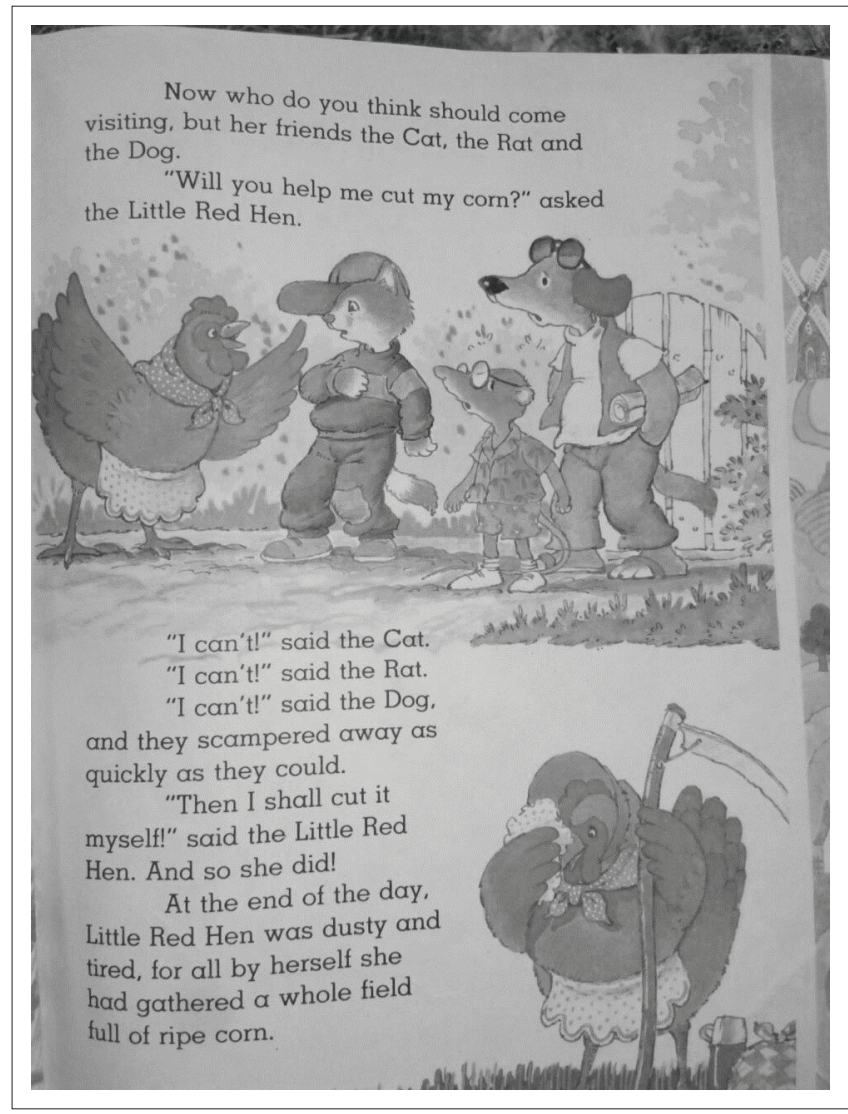

Source: Adapted from Post, R.M., 1979, Children's readers theatre. Language Arts, 56(3), pp.262-267, University of Washington, Seattle, Washington.

FIGURE 1: An example of un-prescribed read aloud story for Grade 4 learners.
This may have denied learners opportunities to learn how to read from relatively better-organised and meaningful content. Figure 2 contains a story from the second reader and seems to be similar to the one in Figure 1 in many respects.

The stories depicted in the figures above are arguably logical and understandable. There are, however, the following discrepancies that formed the basis of the engagement. Even though the first story's title is not depicted on the figure, it appears on the page before. The pictures in Figure 1 seem to follow the story sequentially, from the time when the 'hen' meets her friends to ask for help to the point when she does the work alone after her friends had turned down her request. However, the same could not be said about the sequence of the picture in the second story. The hippo is seeing and watching the crabs having fun, the two birds are said to love each other, and even the turtle is having fun with her two friends on her back. The animals and birds referred to are not shown in the picture in the sequence given in the text. The team considered this matter and agreed that the inclusion of the respective pictures in the sequence given in the text would have eased the teaching and the learners' ability to identify and associate the words (Bouma \& Bouwhuis 1979), such as crabs, birds and turtles, with the respective animals. Instead, the picture in Figure 2 shows a hippo and an elephant in the water (river). This story seems to have taken for granted that learners already knew the hippo and the elephant from their previous experiences.

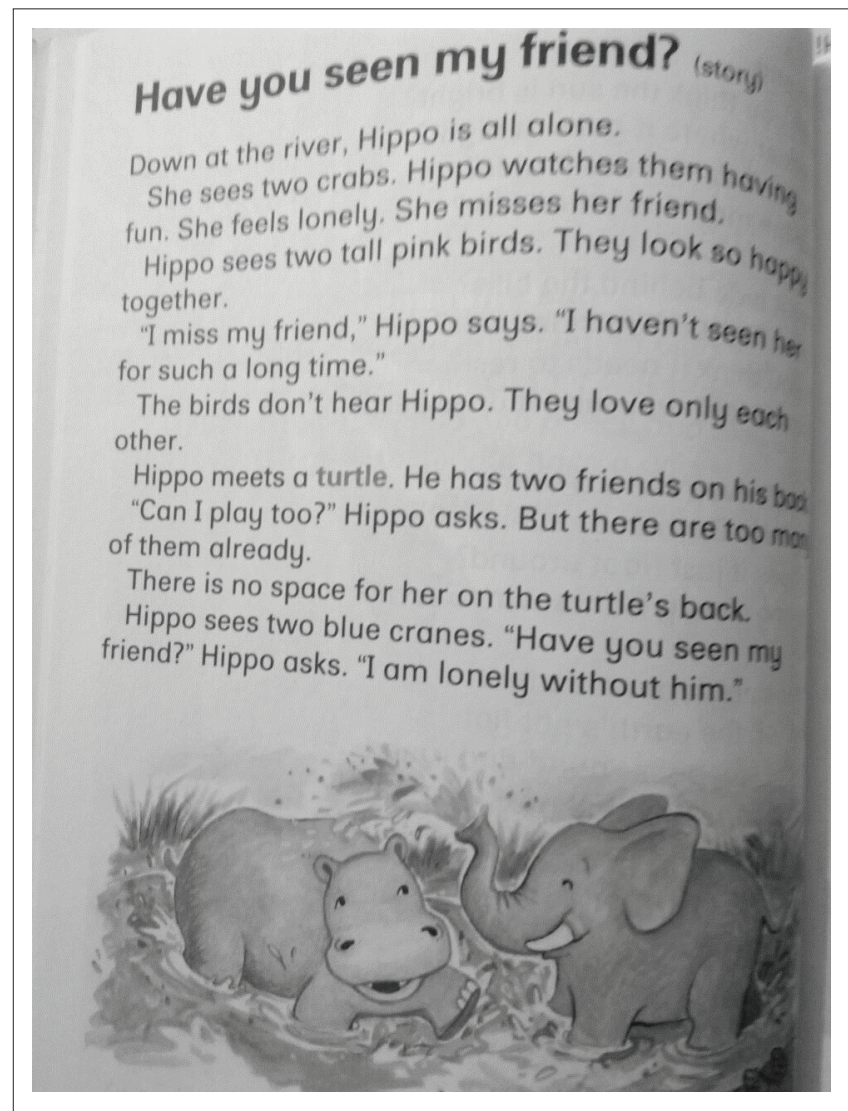

Source: Adapted from Baker, P., Edwards, M., Ralenala, M., Swanepoel, G., Townsend, B. \& Cummins, J., 2014, Platinum English First Additional Language Grade 4 Learner's Book ePUB. Maskew Miller Longman, Pearson, South Africa.

FIGURE 2: An example of a prescribed read aloud story for Grade 4 learners. 
The team contested this notion in light of the learners' rural farm background where there were no such animals. A further contestation was brought about by the lack of clarity whether the elephant was the friend that the hippo was missing, especially seeing that the elephant seemed to be visiting the hippo in the water. Another view was that the elephant was only crossing the river and the hippo asked the elephant whether he or she has not seen the hippo's friend. These and other considerations were also apparent among the learners. During the teaching of reading using this story, learners contested and aired their views, but in their home language, raising their scepticisms about the friendship between the elephant and the hippo. For instance, the four Grade 4 learners, namely Pelaelo, Hlokomelang, Thuso and Kgothatso, conversed about possible information they perceived to be presented by the picture (Figure 2) as follows (Learners conversed in their home language. The translated versions are given):

'... there is no way an elephant can be a friend to a hippo.' (Pelaelo, Grade 4 learner, age 10)

'... animals ... cannot feel lonely ...' (Hlokomelang , Grade 4 learner, age 11)

... animals are always together, like doves always in two or three ...' (Thuso, Grade 4 learner, age 10)

'... doves do not fly together with other birds ... they (doves) do not stay with other birds in their nests ...' (Kgothatso, Grade 4 learner, age 10)

The conversation above formed part of the many sessions of reflection by the team. Team members noted the following issues from the learners' conversation: that learners related the story about the hippo and elephant they did not know with those of the animals they knew, as if the hippo and the elephant would behave in the same way as other animals do. This is evident from Kgothatso's considerations that suggested that only birds (animals) of the same species flock together. Hlokomelang's view seems to disregard the view that animals have 'feelings' like human beings. The question to the team was if 'birds of the same feather that flock together' do so because they have feelings? What are instincts? Our conversations evolved in complexity and we also ended up confused. It was at such junctures of confusion that the study leader enquired from us: 'what more about the confusion we subject our learners to, is this not supposed to be a simple story that helps learners to read fluently and with understanding?', she asked.

Instead of responding to the study leader's question, the first teacher's aide, Thusang, added in frustration that 'the pictures in both stories mystify reality because animals and birds cannot speak a human language (EFAL) and do not dress in human clothes' as the picture suggests. The second teacher's aide, Tshediso, also added that the 'learners' backgrounds are inadequately depicted in the pictures'. He suggested that it would have been helpful if instead of animals, the stories highlighted the plight and experiences of learners and their friendships. Upon further engagement, we realised that the items indicated above have the potential to promote and ease reading in that they render reading systematic and structured in ways that are consistent with the basic principle of teaching and learning, namely, teaching from concrete to abstract, from the known to the unknown (Jarman et al. 2012). Thus, the absence of these priorities or issues seems to contribute towards learners' inability to read fluently and with understanding. This absence is arguably an indication of exclusion and disrespect of learners' backgrounds, experiences and mystification of reality, which in turn render reading irrelevant and meaningless.

The authors subsequently agreed that some stories may actually contribute towards rendering the teaching of reading meaningless and as such adding to the production of underprepared Grade 4 learners. They further agreed that it was unfair and unjust and had the potential to deny learners from schools in rural settings the right to equitable access to quality learning through teaching of reading in EFAL.

\section{Analysing the teaching of reading}

It was imperative to observe how teaching to read progressed from the recognition of letters in words (spelling) to pronunciation and meanings of words in the learners' context (i.e. backgrounds, experiences and home language) (Greer \& Erickson 2018; Stanley, Petscher \& Catts 2018). This had epistemological imperatives on effective teaching of reading in EFAL to Grade 4 learners. For this purpose, the EFAL teacher conducted her normal reading lesson while the other members of the team observed her. The following ensued after all the learners had taken and opened their reading workbooks to the pages as instructed by the teacher:

'Nthabeleng, read the first three lines ...' (Teacher, female)

Nthabeleng was supposed to read the following lines:

Now who do you think should come visiting, but the friends the Cat, the Rat and the Dog.

Nthabeleng: (read with difficulty while she apparently struggled to recognise letters and words, as she read some in her home language)

'No-w w-ho do yo-u thi-nk sho-u-l-d co-me vi-si-ti-ng bu-t the f-rie-n-d-s the c-a-t bu-t the Ra-t a-nd the Do-g.' (Nthabeleng, Grade 4 learner, female)

Teacher: '... (with deep voice and a bored facial expression) 'Ok, Nthabeleng thank you. Next, Seutloadi read ...!' (Teacher, female)

(before Nthabeleng could even finish reading her three lines)

Seutloali: He read in the same manner as Nthabeleng. He read the lines:

'Will you help me cut my corn?' asked the little red hen ...' (Seutloali, Grade 4 learner, male) 
and he read as follows, as though reading letters separately in his home language:

'will y-o-u he-l-p me c-u-t m-y c-o-r-n as-ked the lit-tle red hen

...' (Seutloali, Grade 4 learner, male)

The data above suggest that Nthabeleng and later Seutloali read with difficulty and took a long time to complete their reading to the satisfaction of the teacher. This explains why the teacher did not allow them to read all their allocated sentences. This was apparent from the teacher's non-verbal communication of a 'deep voice' and 'bored facial expression'. What was also of concern was the reading of English words in Sesotho (the learners' home language). For instance, the word 'little', read in two sounds, 'lit' and 'tle', both of which were meaningless in both Sesotho and English, seemed to have negatively influenced the learners' understanding of the word 'little'.

It became evident that the learners were not familiar with the language as they pronounced letters in their home language. The '-' sign between letters indicates how they broke the word into letters (vowels and consonants) in a manner that was consistent with how it would be used in their home language. Albeit from the fact that the teacher did not help the learners as they struggled to spell the words correctly, it became apparent that it was important to consider teaching word recognition, meaning and pronunciation before proceeding with the reading of the sentences.

Good readers recognise words by identifying the component letters, while for fluent readers this is not a conscious process. The converse applies for writing: to form words, writers need to be able to turn the sounds they wish to convey into letters (Stanley et al. 2018). This was necessitated by the observations and findings of the second activity where learners were asked to identify the following words from the flash cards that were pasted on the board:

Cat, cut, rat, red, said, set, sad, rain, but, bat, bed, grain, tired, ripe

All six Grade 4 learners identified cat for cut, red for rat, set for said and bat for but. The reason for these choices seemed to have been influenced by their home language (Sesotho). The ' $u$ ' in cut is pronounced with an ' $a$ ' sound; similarly, the 'aid' sound in said sounds like the ' $\mathrm{e}$ ' sound in set or at best closer to the ' $a$ ' sound in the word sad. This convinced the participants that the influence of home language on the learning and therefore teaching of reading in EFAL was inescapable. It, therefore, became paramount that the teaching of second additional language (EFAL) should take cognisance (Abongdia \& Mpiti 2015) of the possible effect of the home language. Furthermore, this meant that the teacher should consider the teaching of home language sympathetically, as she teaches grades $1-3$ since the school is in a rural setting where multigrade teaching is the norm.

\section{Post-class reflection}

The team reflected on the reading lesson to determine from the teacher (lesson presenter) what she thought progressed well or not so well, and how to address the areas of weakness. In the same manner, the other members responded to the three issues as per their respective observations. For purposes of this argument, the team focussed on the issue of the lesson plan and its implementation, as it appeared to be a dominant concern for the team. In her response to how she had planned to teach learners on that particular day, the teacher responded:

'... there is no way I can have a lesson plan for teaching reading, writing and language ...' (Teacher, female)

The team sought to understand the reason why that was the case, and she added:

'... the work is just too much from Grade 1 to 6 , for six subjects ... impossible ...' (Teacher, female)

That the teacher has much work and as a result does not plan her lessons was cause for concern for the team. This was in view of the positive influence that a good lesson plan has on teaching. The team agreed that by implementing a good lesson plan(s), learners' actual learning can be tracked; inadequacies can also be traced and appropriately responded to. For instance, clear objectives, which inform the choice and use of learning support materials and resources, compel the teacher to ensure their use and the assessment of the extent to which the objectives are achieved (DBE 2011). This seems to explain why the teacher did not use the resources available and did not intervene in order to provide the necessary support. She did not have a plan. A serious concern was the apparent deprivation of learners' opportunities to learn how to read. Furthermore, the absence of a lesson plan in a multigrade class of a one-teacher school, where there was 'no way ...' the only teacher 'can have a lesson plan ...' was a serious concern for the team. They viewed the act as unfortunate and socially unjust, as it had the capacity to render the school an institution where learning was not important. The team found that written lesson plans were fundamental, especially under the circumstances outlined above. It has the potential to transform the teaching of reading, especially if learners' backgrounds, experiences and culture inform their learning.

\section{Conclusion}

The findings that are presented with the analysis of data above demonstrate and justify the suitability of SITS where the teaching of reading, EFAL in this case, is to be enhanced. SITS proved to have an impact where there are limitations or challenges with respect to the following:

- Teacher support: in this case, teaching of reading to ease the workload of the only teacher at the school, who had administrative, management and leadership roles while focussing on attainment of actual teaching and learning outcomes.

- Learning needs: the transition from home language to second language, in this case from Sesotho to EFAL, offers opportune moments for the application of SITS. The inclusion of learners' backgrounds and experiences, coupled with the involvement of parents and youth from 
the community in the process of enhancing learning environments through SITS, is phenomenal.

- Learning and teaching support material (LTSM): the transition from home language to second language also tends to lean towards the development and production of LTSM that lean towards urban environments. The need to develop LTSMs that are relevant and meaningful by reflecting indigenous knowledge systems embedded in the rural and farm settings, and which demystify reality, is inevitable.

\section{Recommendations}

The team members tried out the following recommendations in the area of the study and presented them on the basis that they were realisable (are implementable). They recommend:

- Team work for the teaching of reading in the second additional language (EFAL) to multigrade classes, in particular in one-teacher schools in rural settings. The team should comprise parents, members of community development organisations and other people with vested interests in combating potentially socially unjust acts of depriving learners an opportunity to learn. The roles of members should be jointly determined and be aligned to their interests and other responsibilities as far as practicable. Team members should be involved from the conception of the reading project, through the development of the project plan, the implementation, and the reflective engagements that seek to improve immanent shortcomings that manifest throughout the process.

- The team should conduct a situational analysis as their first activity. The purpose should be to determine the strengths, weaknesses, opportunities and threats (SWOT) that are inherent in the area of the project (i.e. EFAL reading project). The political, economic, research and technological (PERT) aspects of the situation, whether internal or external to the project, should be kept in mind. This analysis process should help the team to develop a plan according to which the teaching of reading in EFAL is conducted. Among the items to be subjected to this rigorous process are the reading material, the actual teaching process and the post-lesson presentation reflections. For each of these items, the team should be clear about the criteria which should consistently explain the execution of the plan. It is also imperative to be aware that the criteria must be open to critique for purposes of further enhancement.

- Developing enhancing measures and mechanisms for teaching reading by the team. Among these mechanisms the following are instructive:

- Planning the lesson together (as a team) and making decisions about, among others, the structure of the lesson plan, critical items that are to be included in the lesson plan, resources and methods of teaching, the learners' activities, as well as the roles of the team members during actual teaching of reading.

- Collaborative decision-making with respect to consensus on inter alia, who to present the lesson and the roles of the other participants during the actual delivery of the lesson plan.
- Development of learning support material that is relevant to rural backgrounds and consistent with learners' experiences and cultural backgrounds. These issues need to be sensitive not to mystify reality to the extent of influencing learning negatively.

\section{Acknowledgements}

I would like to thank my supervisor for his undivided attention and the institution for creating a conducive research environment and for funding my research work.

\section{Competing interests}

The authors declare that they have no financial or personal relationships that may have inappropriately influenced them in writing this article.

\section{Authors' contributions}

M.L.M. contributed to the formulation of the article, retrieved from her PhD study of which S.M. was her PhD study leader; therefore, M.L.M. felt she has to acknowledge her promoter. M.F.T. became M.L.M.'s supervisor while holding a postdoctoral fellowship position, and his contribution was to help in addressing the second round reviewer's comments. Together with M.L.M., M.F.T. restructured the article according to the reviewer's suggestions.

\section{References}

Abongdia, J.F.A. \& Mpiti, T., 2015, 'Learners' experiences of writing in English first additional language', International Journal of Educational Sciences 11(1), 91-96. https://doi.org/10.1080/09751122.2015.11890378

Alberta Education, 2010, Arts, communications and citizenship. Literacy first: A plan for action, Government of Alberta, Alberta, Canada.

Armstrong, M.A., 2011, 'Small world: Crafting an inclusive classroom (no matter what you teach)', Thought and Action, Fall, 51-61.

Baker, P., Edwards, M., Ralenala, M., Swanepoel, G., Townsend, B. \& Cummins, J., 2014, Platinum English First Additional Language Grade 4 Learner's Book ePUB. Maskew Miller Longman, Pearson, South Africa

Bouma, H. \& Bouwhuis, D., 1979, 'Visual word recognition of three-letter words as derived from the recognition of the constituent letters', Perception \& Psychophysics 25(1), 12-22. https://doi.org/10.3758/BF03206104

Bruwer, M., Hartell, C. \& Steyn, M., 2014, 'Inclusive education and insufficient school readiness in Grade 1: Policy versus practice', South African Journal of Childhood Education 4(2), 18-35, Aosis, Cape Town.

Burnes, B. \& Cooke, B., 2013, 'Kurt Lewin's field theory: A review and re-evaluation' International Journal of Management Reviews 15(4), 408-425.

Chomsky, N. \& Foucault, M., 2006, The Chomsky-Foucault debate on human nature, The New Press, New York.

Christie, J.F., Enz, B.J. \& Vukelich, C., 2011, Teaching language and literacy. Preschool through the elementary grades, Pearson, Boston, MA

Corcoran, S.P., 2010, Can teachers be evaluated by their students' test scores? Should they be? The use of value-added measures of teacher effectiveness in policy and practice, Education Policy for Action Series, Annenberg Institute for School Reform at Brown University, New York.

Das, A. \& Kattumuri, R., 2011, Children with disabilities in private inclusive schools in Mumbai: Experiences and challenges, Working Papers 34, LSE Asia Research Centre, viewed 20 September 2018, from http://eprints.Ise.ac.uk/38362/1/ ARCWP34-DasKattumuri.pdf

Department of Basic Education (DBE), 2009, Report of the task team for the review of the implementation of the National Curriculum Statement, Government Printer, Pretoria.

Department of Basic Education (DBE), 2011, Report on the qualitative analysis of Annual National Assessment 2011 results, Government Printer, Pretoria.

Department Basic Education (DBE), 2014, Report on the annual national assessment, Government Printer, Pretoria.

Department of Education, 2005, Guidelines for inclusive learning programmes, Government Printer, Pretoria. 
Desforges, C. \& Abouchaar, A., 2003, The impact of parental involvement, parental support and family education on pupil achievement and adjustment: A review of support and family education on pupil achievement and adjustment:
the literat Report 433, DfES Publications, Nottingham.

Devereaux, R., 2013, Definition of socially inclusive, viewed 10 May 2013, from http:// www.ehow.com/about-5480210-definition-socially-inclusive.html

Eggen, P. \& Kauchak, D., 2008, Introduction to teaching: Becoming a professional, Pearson, Upper Saddle River, NJ.

Ehri, L., 2005, 'Learning to read words: Theory, findings, and issues', Scientific Studies of Reading 9(2), 167-188. https://doi.org/10.1207/s1532799xssr0902_4

Faulker, D., 2011, Building strong and inclusive communities. Social Inclusive Strategy 2008-2011, City Council, Newcastle.

Feiman-Nemser, S., 2001, 'Helping novices learn to teach: Lessons from an exemplary support teacher', Journal of Teacher Education 52(1), 17-30. https://doi. org/10.1177/0022487101052001003

Gentry, R., 2010, Raising confident readers: How to teach your child to read and write from baby to age 7, Da Capo/Lifelong, New York.

Greer, C.W. \& Erickson, K.A., 2018, 'A preliminary exploration of uppercase lettername knowledge among students with significant cognitive disabilities', Reading and Writing 31(1), 173-183. https://doi.org/10.1007/s11145-017-9780-y

Henning, E., Van Rensburg, W. \& Smit, B., 2004, Finding your way in qualitative research, Van Schaik, Pretoria.

Jarman, R., McClune, B., Pyle, E. \& Braband, G., 2012, 'The critical reading of the images associated with science-related news reports: Establishing a knowledge, skills, and attitudes framework', International Journal of Science Education, Part B 2(2), 103-129. https://doi.org/10.1080/21548455.2011.559961

Kemmis, S. \& McTaggart, R., 2007, 'Participatory action research: Communicative action and the public sphere', in N.K. Denzin \& Y.S. Lincoln (eds.), Strategies of qualitative inquiry, pp. 271-330, Sage, Thousand Oaks, CA.

Kincheloe, J. \& Steinberg, S., 1998, 'Students-as-researchers: Critical visions, emancipatory insights', in J. Kincheloe \& S. Steinberg (eds.), Students-as-researchers: Creating classrooms that matter, pp. 2-19, The Falmer Press, London.

Kirby, S., Griffiths, T. \& Smith, K., 2014, 'Iterated learning and the evolution of language', Current Opinion in Neurobiology 28, 108-114. https://doi.org/ 10.1016/j.conb.2014.07.014

Madiba, M., 2013, Academic literacy at foundation phase level: An exploratory investigation report, Umalusi, Pretoria.

Mahlomaholo, S.M.G., 2013, 'Creating sustainable learning environments through socially inclusive research', A Research report submitted to the discipline of Psychology, Faculty of the Humanities, University of the Free State, South Africa.

Malebese, L.M., 2016, 'A socially inclusive teaching strategy to respond to problems of literacy in a Grade 4 class', Doctoral dissertation, University of the Free State, Bloemfontein.

Mertens, D. \& Yamashita, M., 2010, Mission statement for the American Evaluation Association's Topical Interest Group: Mixed methods in evaluation, Sage, Thousand Oaks, CA.

Meulenberg-Buskens, I., 1996, 'Critical awareness in participatory research: an approach towards teaching and learning', in K. De Koning \& M. Martin (eds.),
Participatory research in health: Issues and experiences, pp. 40-49, Zed Books, Liverpool.

Nel, N. \& Müller, H., 2010, 'The impact of teachers' limited English proficiency on English second language learners in South African schools', South African Journal of Education 30(4), 635-650. https://doi.org/10.15700/saje.v30n4a393

Ofulue, C.I., 2011, 'Literacy at a distance in multilingual contexts: Issues and challenges', The International Review of Research in Open and Distributed Learning 12(6), 84-101.

Pedretti, E. \& Nazir, J., 2011, 'Currents in STSE education: Mapping a complex field, 40 years on', Science Education 95(4), 601-626. https://doi.org/10.1002/ sce. 20435

Post, R.M., 1979, Children's readers theatre. Language Arts, 56(3), pp.262-267, University of Washington, Seattle, Washington.

Scharer, P.L., 2012, Policy into practice. What is reading?, Ohio University Press, Columbus, $\mathrm{OH}$.

Shepherd, J., 2012, 'Literacy problems show Charles Dickens's world persists, says minister. Schools minister Nick Gibb says literacy problems are still heavily oriented towards poorest', The Guardian, 07 February, p. 1.

Stanley, C.T., Petscher, Y. \& Catts, H., 2018, 'A longitudinal investigation of direct and indirect links between reading skills in kindergarten and reading comprehension in tenth grade', Reading and Writing 31(1), 133-153. https://doi.org/10.1007/ s11145-017-9777-6

Taylor, N., 2016, 'Thinking, language and learning in initial teacher education', Perspectives in Education 34(1), 10-26. https://doi.org/10.18820/2519593X/pie. v34i1.2

Thomson, P., Hall, C. \& Jones, K., 2013, 'Towards educational change leadership as a discursive practice - Or should all school leaders read Foucault?', International Journal of Leadership in Education 16(2), 155-172.

UNESCO, 2012, UNESCO global partnership for girls and women's education - One year on, viewed 20 September 2018, from http://www.unesco.org/new/en/ education

Van Dijk, T.A., 2003, 'The discourse-knowledge interface', in Weiss G., Wodak R. (eds) Critical discourse analysis, pp. 85-109, Palgrave Macmillan, London.

Van Dijk, T.A., 2009, 'Critical discourse studies. A sociocognitive approach', in R. Wodak \& M. Meyer (eds.), Methods for critical discourse analysis, pp. 62-86, Sage, London.

Vygotsky, L., 1978, Social development theory, viewed 23 October 2017, from http:// www.tip.psychology.org/vygotsky.html

Wetere, R.H., 2009, Addressing the literacy issues of Canada's Aboriginal population A discussion paper, Arrowmight, Ottawa, Canada.

Weybright, E.H., Caldwell, L.L., Xie, H., Wegner, L. \& Smith, E.A., 2017, 'Predicting secondary school dropout among South African adolescents: A survival analysis approach', South African Journal of Education 37(2), 1-11.

Woolfolk, A., 2007, Educational psychology, Allyn \& Bacon, Boston, MA.

Yosso, T.J., 2005, 'Whose culture has capital? A critical race theory discussion of community cultural wealth', Race Ethnicity and Education 8(1), 69-91. https://doi. org/10.1080/1361332052000341006 